Central Washington University ScholarWorks@CWU

$8-2010$

\title{
Slip Distribution of the 1952 Kamchatka Great Earthquake Based on Near-Field Tsunami Deposits and Historical Records
}

Breanyn MacInnes

University of Washington - Seattle Campus, macinnes@geology.cwu.edu

Robert Weiss

Texas A \& $M$ University - College Station

Joanne Bourgeois

University of Washington - Seattle Campus

Tatiana K. Pinegina

Institute of Volcanology and Seismology, Russia

Follow this and additional works at: http:// digitalcommons.cwu.edu/cotsfac

Part of the Environmental Indicators and Impact Assessment Commons, Geophysics and Seismology Commons, and the Tectonics and Structure Commons

\section{Recommended Citation}

MacInnes, B.T., Weiss, R., Bourgeois, J., \& Pinegina, T.K. (2010). Slip distribution of the 1952 Kamchatka Great Earthquake based on near-field tsunami deposits and historical records. Bulletin of the Seismological Society of America, 100(4), 1695-1709. DOI: 10.1785/ 0120090376 


\section{Bulletin of the Seismological Society of America}

This copy is for distribution only by

the authors of the article and their institutions in accordance with the Open Access Policy of the Seismological Society of America.

For more information see the publications section of the SSA website at www.seismosoc.org

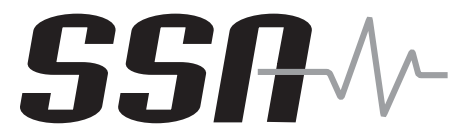

The Seismological Society of America 400 Evelyn Ave., Suite 201

Albany, CA 94706-1375

(510) 525-5474; FAX (510) 525-7204

www.seismosoc.org 


\title{
Slip Distribution of the 1952 Kamchatka Great Earthquake Based on Near-Field Tsunami Deposits and Historical Records
}

\author{
by Breanyn T. MacInnes, Robert Weiss, Joanne Bourgeois, and Tatiana K. Pinegina
}

\begin{abstract}
We explore the magnitude and slip distribution of the 1952 Kamchatka earthquake $\left(M_{\mathrm{w}}\right.$ 8.8-9.0) using constraints from the 1952 Kamchatka tsunami. Our new field data provide more comprehensive coverage of the near-field tsunami than had been available to date. We examine the effects of internal slip distribution within complex earthquake ruptures on near-field tsunami runup and evaluate some of the limitations of this approach. Our approach compares tsunami-deposit distribution with simulated runup from tsunamis generated by different configurations of seafloor deformation from hypothetical earthquakes resembling that of the 1952 Kamchatka earthquake. We identify areas of high slip because different distributions of seafloor deformation result in variations in tsunami runup in the near field. Mapped deposits and local observations of the 1952 Kamchatka tsunami indicate that near-field runup in central Kamchatka was consistently less than $10 \mathrm{~m}$ (averaging $6 \mathrm{~m}$ ), while south Kamchatka to the northern Kuril Islands had more variability and higher average runup ( $8 \mathrm{~m}$ runup in South Kamchatka and $10 \mathrm{~m}$ runup in the northern Kuril Islands). Our simulations show that in order to produce the distribution of runup indicated by tsunami deposits and historical observations, the 1952 earthquake had regions of high slip off the coast of southern Kamchatka, and the location of high slip is shallower in the subduction zone than previously interpreted.
\end{abstract}

Online Material: Sedimentary methodology, model inputs, and simulation results.

\section{Introduction and Background}

In this paper, we show how tsunami-deposit distribution can help determine earthquake magnitude and slip distribution for the specific case of the great 1952 Kamchatka earthquake $\left(M_{\mathrm{w}} 8.8-9.0\right)$. This earthquake occurred in a sparsely populated, largely restricted area and before widespread modern instrumentation, so, although this earthquake remains one of the largest instrumentally recorded, the specifics of its magnitude and slip distribution remain imprecise. Our field study of tsunami deposits associated with this event has more than doubled the number of accurately located observations in the near field (the coastal zone parallel to the zone of rupture). With this denser array of data, we examine models for slip distribution of the 1952 Kamchatka earthquake.

Unraveling the details of earthquakes and tsunamis requires a dense array of data or very sensitive recorders, so even relatively recent, remote events can be difficult to reconstruct. Records of modern and historical tsunamis from buoys deployed in the deep sea and tide gauges have been used to investigate earthquake rupture characteristics (Johnson and Satake, 1999; Hirata et al., 2003; Ichinose et al., 2007; Borrero et al., 2009; Hébert et al., 2009). However, similar records of tsunami waveforms do not exist for paleo- events or for large historical tsunamis in their near field, where the tsunami or earthquake destroys most instrumentation. Records of prehistoric and sans-instrumental earthquakes are primarily limited to evidence for strong shaking, such as liquefaction structures (Obermeier, 2005), evidence for rupture and abrupt land-level change (Satake and Atwater, 2007; McCalpin, 2009), and preserved tsunami deposits (Bourgeois, 2009). Of these forms of geologic evidence, our work focuses on tsunami deposits.

Tsunamis link directly to the earthquakes that generated them and reflect details of earthquake characteristics (Okal, 2009). While secondary processes, such as submarine slumping, splay faulting, etc., can enhance tsunamis, recent studies have shown that tsunami runup in the near field is sensitive to earthquake slip distribution and other source characteristics (Geist 2002; Hirata et al. 2003; Okal and Synolakis, 2004; Satake et al., 2008; Borrero et al., 2009). Thus, by studying tsunami records, we can learn more about historical earthquakes, as well as about prehistoric earthquakes (Martin et al., 2008; Satake et al., 2008). Such records include catalogs of tsunami height, survey maps of tsunami inundation, and the distribution of tsunami deposits. 
The extent of a tsunami deposit is a proxy for minimum tsunami inundation (horizontal distance of tsunami penetration measured landward from the shoreline) and runup (elevation above mean sea level, MSL, at inundation). Therefore, deposit distribution along a coastline can record spatial variations in a tsunami's form. This distribution can inform us about rupture characteristics of an earthquake when we use standard forward modeling techniques (Liu, 2009; Imamura, 2009) to propagate tsunamis from an initial seafloor disturbance and then compare the simulated runup distribution to observed sediment distribution.

Examining cases that have some historical and instrumental records, like the 1952 Kamchatka earthquake and tsunami pair, not only can elucidate the earthquake itself but also helps paleoseismologists address basic goals of paleoseismology, which include identification of recurrence intervals, magnitudes, and source characteristics of paleotsunamis and paleoearthquakes. Because we have more than doubled the existing records for 1952 Kamchatka and other historical tsunamis in the Russian Far East with our studies of tsunami deposits, this location can help bridge the boundary between seismology and paleoseismology with respect to the use of tsunami geology. Our goal is to test a technique that eventually can be applied to paleoevents-those without direct record of an earthquake.

\section{Factors in Local Tsunami-Amplitude Variations}

For any given seismic moment, near-field tsunamis can be significantly influenced by depth of rupture and amount and distribution of slip (Geist and Dmowska, 1999; Geist, 2002; Satake et al., 2008; Okal, 2009). Heterogeneous rupture patterns are expected for all earthquakes but are more noticeable in large events (as in Johnson and Satake, 1997; Ishii et al., 2005). In a test case, Geist (2002) calculates a factorof-three variation in peak tsunami amplitudes in the near field due to differences in earthquake slip distributions for theoretical $M_{\mathrm{w}} 8.1$ earthquakes along the coast of Mexico. He concludes that, other than seismic moment, the most important determinants of tsunami waveforms are (1) high slip and low shear modulus along the shallowest sections of the subduction zone, (2) variations in water depth in the rupture area, and (3) heterogeneous slip distribution reflecting both depth and along-strike variations of the rupture. The first parameter is responsible for a tsunami earthquake (Kanamori, 1972; Pelayo and Wiens, 1992; Satake and Tanioka, 1999). The second parameter, local bathymetry, causes variations or perturbations in the initial waveform and propagation of the tsunami wave (Liu, 2009). Heterogeneities in depth (slip variations down dip) affect the vertical displacement field and generate different initial wave profiles than homogeneous ruptures (Tadepalli and Synolakis, 1996). Variations in slip along strike also result in spatial amplitude changes along the wavefront (Geist and Dmowska, 1999).

\section{Kamchatka Earthquake and Tsunami}

The 1952 Kamchatka great earthquake (Fig. 1) began at 16:58:22 Greenwich mean time on 4 November and is considered the fourth largest historical event, after 1960 Chile, 1964 Alaska, and 2004 Sumatra-Andaman earthquakes (Brune and Engen, 1969; Kanamori, 1976; Okal, 1992; Lay et al., 2005). Its seismological characteristics have been relatively well studied (compare Hutchinson, 1954; Hodgson, 1956; Brune and Engen, 1969, Kelleher and Savino, 1975; Kanamori, 1976; Johnson and Satake, 1999). These studies constrain the earthquake's rupture location and magnitude, but, because of data and technology limits in 1952 , the error range is large by today's standards.

The tsunami following the 1952 Kamchatka earthquake had measurable runup around the world and was particularly damaging in the near field, destroying many of the villages and towns along the Pacific coastlines of southern Kamchatka and the northern Kuril Islands (Soloviev and Go, 1984; Zayakin and Luchinina, 1987; Kaistrenko and Sedaeva, 2001; Nikonov, 2006). Existing catalogs have about 300 far-field data points and 30 near-field data points (see Data and Resources section). Local observations were limited due to a dispersed population; and, because the earthquake and tsunami occurred at the height of the Cold War, direct observations and human experiences from Kamchatka and the Kurils of the earthquake and tsunami only recently are becoming available to the rest of the world (Kaistrenko and Sedaeva, 2001; Nikonov, 2006).

The generally accepted rupture area of the 1952 earthquake (Fig. 1) is approximately $700 \mathrm{~km}$ long, from northern Onekotan Island $\left(49^{\circ} \mathrm{N}\right)$ to Shipunskii Cape $\left(52.5^{\circ} \mathrm{N}\right)$, and is 150-200 km wide. A cluster of foreshocks (Fig. 2) in the two

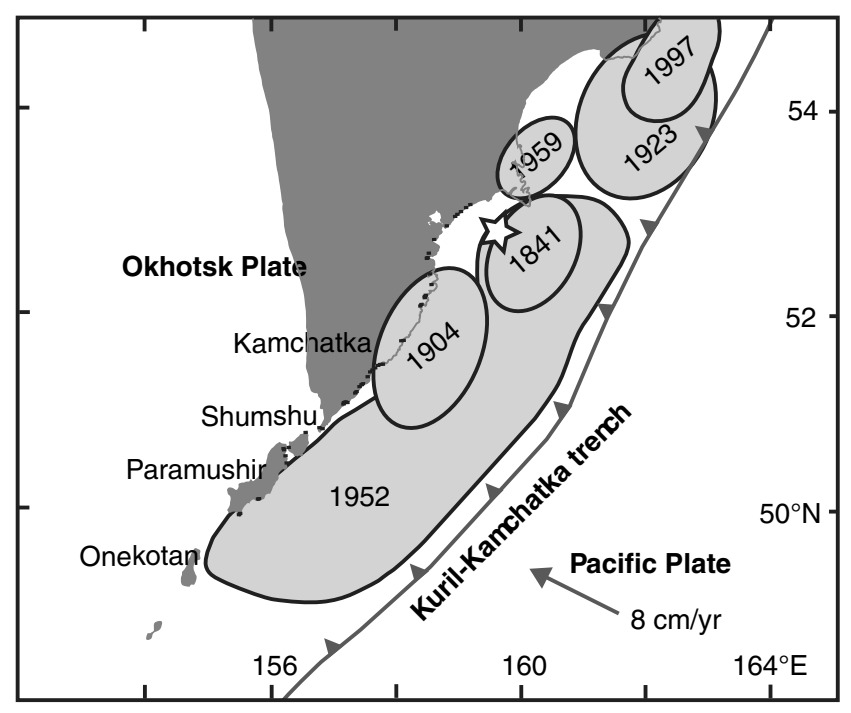

Figure 1. Tectonic setting and the inferred rupture areas of tsunamigenic subduction-zone earthquakes (locations after Fedotov et al., 1982, 1999). The star represents the 1952 epicenter. The rupture zones and epicenters for two events in the eighteenth century (1737 and 1792) are unknown. Refer to Table 2 for more information. 


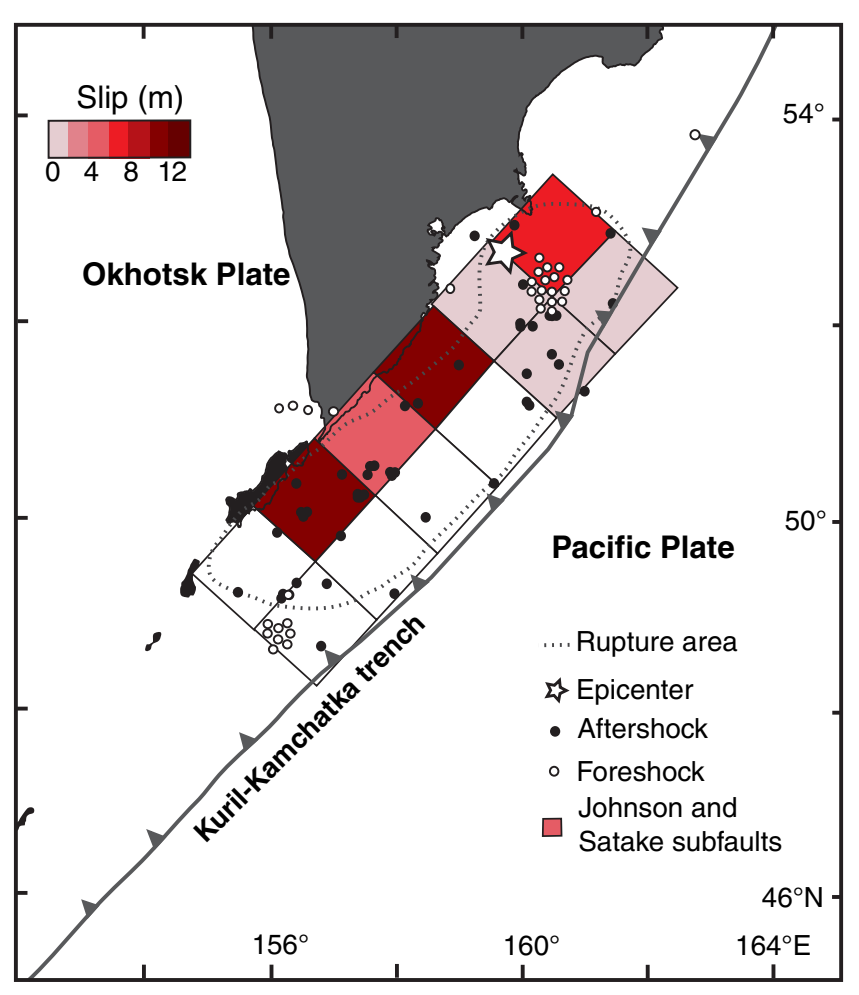

Figure 2. The preferred slip distribution for the 1952 Kamchatka earthquake determined by Johnson and Satake, 1999. Major aftershocks (from Fedotov et al., 1982) and foreshocks (from Balakina, 1992) help define the inferred rupture area. The color version of this figure is available only in the electronic edition.

years before the earthquake occurred near both the epicenter and the southern end of the rupture zone (Kelleher and Savino, 1975; Balakina, 1992). Aftershocks within one month of the earthquake (Fig. 2) have been used to define the northern limit of the rupture (Ben-Menahem and Toksöz, 1963; Kelleher and Savino, 1975; Fedotov et al., 1982). Earlier studies proposed a rupture area $1000 \mathrm{~km}$ by $250 \mathrm{~km}$ (Bath and Benioff, 1957), but the larger area is considered to include earthquakes that are not aftershocks (Ben-Menahem and Toksöz, 1963). Slip direction appears to have been roughly perpendicular to the subduction zone (Kanamori, 1976).

The amount and distribution of slip and the total seismic moment are less certain than the location; original studies considered the earthquake to have $\sim 5 \mathrm{~m}$ of homogeneous slip over the entire area (e.g., Kanamori, 1976). There are relatively few records of the earthquake from global seismic stations, some of questionable quality (Kanamori, 1976). Even different analyses based on the same records (e.g., Kanamori, 1976; Okal, 1992) have yielded somewhat different earthquake magnitudes. Published estimates of seismic moment range from $180 \times 10^{20}$ to $350 \times 10^{20} \mathrm{Nm}$, corresponding to a moment magnitude between $M_{\mathrm{w}} 8.84$ and $M_{\mathrm{w}} 9.03$ (Johnson and Satake, 1999).

Using a different approach, Johnson and Satake (1999) calculated heterogeneous slip on possible $100 \times 100 \mathrm{~km}$ segments of the 1952 rupture zone by inverting tide-gauge records of tsunami waves in the far field. They proposed a varying slip of up to $11.4 \mathrm{~m}$, with high coseismic slip predicted to have occurred only in sections of the subduction zone deeper than about $20 \mathrm{~km}$ (Fig 2). Earlier studies of 1952 seismic records similarly suggested a deeper-thanaverage subduction-zone event: up to $40 \mathrm{~km}$ (Hutchinson, 1954) or even 60-80 km (Ben-Menahem and Toksöz, 1963). Johnson and Satake (1999) suggest that such deep slip would make the 1952 earthquake anomalous for tsunamigenic subduction-zone earthquakes in that the largest amount of slip did not occur near the trench.

Additional evidence that the 1952 Kamchatka rupture was heterogeneous comes from recent Global Positioning System (GPS) analysis of asperity distribution. Bürgmann et al. (2005) used recent GPS measurements and the analyses of Johnson and Satake (1999) to identify two or three potentially persistently locked regions in the Kuril-Kamchatka subduction zone that correspond to regions of slip $\geq 5 \mathrm{~m}$ calculated by Johnson and Satake (1999). Also, Johnson and Satake's areas with the highest proposed slip $(\geq 10 \mathrm{~m})$ have a notably low count of aftershocks from 1952 (Fig. 2), supporting the idea that these regions relocked immediately after rupture.

Field Observations: Historical Records and Deposits of the 1952 Kamchatka Tsunami

We reconstructed the 1952 Kamchatka tsunami in the near field on the basis of two kinds of information: historical observations (recorded in catalogs and other publications or papers) and tsunami deposits. Hereafter, we refer to the combination of historical records and sediment data collectively as field observations. For each field observation, we determine an estimate of inundation and runup, which we compare to simulations of the 1952 tsunami.

Historical Runup and Inundation Data for the 1952

Kamchatka Tsunami in the Near Field

From published records, we used nine observations (Table 1) with known latitudes and longitudes from the Historical Tsunami Database for the World Ocean (HTDBWLD database; see Data and Resources section), which compiles prior catalog data. Observations in the HTDBWLD database are not necessarily measurements of tsunami runup; most likely the wave height was measured near a settlement or military outpost. These data also do not include inundation distances, which we calculated from latitude and longitude of the observation point and the adjacent shore. We used an additional eight locations (Table 1) from a post-tsunami survey conducted by members of the Second Navy Hydrographic Expedition, who mapped tsunami inundation in 1953 (Kaistrenko and Sedaeva, 2001). Observations from this post-tsunami survey include maps of tsunami runup and inundation and therefore are more reliable than observations in the HTDBWLD database. 
Table 1

Field Observations of Runup and Inundation of the 1952 Kamchatka Tsunami

\begin{tabular}{|c|c|c|c|c|c|c|c|c|}
\hline \multirow[b]{2}{*}{ Site Location } & \multirow[b]{2}{*}{ Latitude } & \multirow[b]{2}{*}{ Longitude } & \multirow[b]{2}{*}{$\begin{array}{l}\text { Sediment Limit } \\
\text { Observed? }\end{array}$} & \multicolumn{2}{|c|}{ Runup (m) } & \multicolumn{2}{|c|}{ Inundation (m) } & \multirow[b]{2}{*}{$\begin{array}{l}\text { Acceptable Range } \\
\text { for Simulations (m) }\end{array}$} \\
\hline & & & & Sediment & Water & Sediment & Water* & \\
\hline Vasil'eva & 50.0346 & 155.3980 & no & 8.4 & & 117 & & $7.9-\infty$ \\
\hline Vasilyeva east ${ }^{\dagger}$ & 50.0502 & 155.4267 & 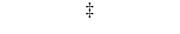 & & 6.2 & & 500 & $5.0-7.2$ \\
\hline Ocean Bay ${ }^{\dagger}$ & 50.1840 & 155.7650 & $\ddagger$ & & 7.0 & & 300 & $6.0-8.0$ \\
\hline Okeanskaya & 50.1898 & 155.7445 & no & 8.2 & & 174 & & $7.7-\infty$ \\
\hline Paramushir 3 & 50.5351 & 156.1480 & no & 5.4 & & 214 & & $4.9-\infty$ \\
\hline Paramushir 4 & 50.5687 & 156.1475 & no & 16.8 & & 211 & & $16.3-\infty$ \\
\hline S Severo-Kurilsk ${ }^{\dagger}$ & 50.6707 & 156.1254 & $\ddagger$ & & 9.0 & & 1200 & $8.0-10.0$ \\
\hline N Severo-Kurilsk ${ }^{\dagger}$ & 50.6902 & 156.1269 & $\ddagger$ & & 7.0 & & 400 & $6.0-8.0$ \\
\hline Kozyrevsk $^{\dagger}$ & 50.7024 & 156.1804 & $\ddagger$ & & 7.0 & & 400 & $6.0-8.0$ \\
\hline Baikovo $^{\S}$ & 50.7187 & 156.1947 & $\ddagger$ & & $9^{\S}$ & & 60 & $7.0-11.0$ \\
\hline Shumshu 3 & 50.8645 & 156.4794 & no & 15.6 & & 183 & & $15.1-\infty$ \\
\hline E Cape Lopatka $^{\dagger}$ & 50.8708 & 156.6711 & $\ddagger$ & & 15.0 & & 200 & $9.0-12.0$ \\
\hline W Cape Lopatka ${ }^{\dagger}$ & 50.8808 & 156.6595 & $\ddagger$ & & 10.0 & & 250 & $14.0-16.0$ \\
\hline Three Sisters 3 & 51.1452 & 157.0783 & yes & 7.5 & & 166 & & $7.0-9.0$ \\
\hline Three Sisters 4 & 51.1475 & 157.0824 & no & 7.2 & & 395 & & $6.7-\infty$ \\
\hline Three Sisters 1 & 51.1558 & 157.0968 & no & 3.8 & & 345 & & $3.3-\infty$ \\
\hline Three Sisters 5 & 51.1574 & 157.1010 & no & 18.0 & & $150^{*}$ & & $17.5-\infty$ \\
\hline Ushatnaya 5 & 51.2738 & 157.2780 & no & 3.6 & & 405 & & $3.1-\infty$ \\
\hline Ushatnaya 6 & 51.2769 & 157.2870 & no & 17.4 & & 202 & & $16.9-\infty$ \\
\hline Utyuzhnaya 9 & 51.3379 & 157.3480 & no & 6.5 & & 506 & & $8.3-\infty$ \\
\hline Utyuzhnaya 7 & 51.3528 & 157.3750 & no & 6.6 & & 516 & & $2.4-\infty$ \\
\hline Utyuzhnaya 8 & 51.3564 & 157.3910 & no & 6.5 & & 494 & & $6.0-\infty$ \\
\hline Vestnik 10/11 & 51.4275 & 157.4735 & no & 9.9 & & 1366 & & $9.4-\infty$ \\
\hline Vestnik 12 & 51.4479 & 157.4890 & yes & 10.8 & & 875 & & $10.0-11.0$ \\
\hline Vestnik 13 & 51.4701 & 157.5060 & no & 7.6 & & 1037 & & $7.1-\infty$ \\
\hline Vestnik 1 & 51.4861 & 157.5300 & yes & 8.8 & & 643 & & $8.3-16.7$ \\
\hline Vestnik 2 & 51.5158 & 157.5778 & yes & 5.4 & & 872 & & $4.5-11.0$ \\
\hline Vestnik $^{\S}$ & 51.5444 & 157.6520 & $\ddagger$ & & $8.3^{\S}$ & & 890 & $6.3-10.3$ \\
\hline Vestnik 3 & 51.5605 & 157.6890 & no & 5.5 & & 1000 & & $5.0-\infty$ \\
\hline Khodutka ${ }^{\S}$ & 51.7751 & 158.0050 & $\ddagger$ & & $2^{\S}$ & & 880 & $0.0-4.0$ \\
\hline Khodutka 1 & 51.7803 & 158.0090 & yes & 4.4 & & 1038 & & $2.5-12.7$ \\
\hline Asacha $^{\S}$ & 52.1208 & 158.3070 & $\ddagger$ & & $7 \S$ & & 200 & $5.0-9.0$ \\
\hline Asacha 1 & 52.1394 & 158.3344 & yes & 4.9 & & 332 & & $4.4-6.9$ \\
\hline Mutnaya G & 52.1921 & 158.3820 & no & 5.2 & & 385 & & $3.6-\infty$ \\
\hline Mutnaya 1 & 52.1937 & 158.3730 & yes & 4.1 & & 975 & & $3.5-9.9$ \\
\hline Mutnaya 2 & 52.2094 & 158.3720 & no & 5.2 & & 953 & & $4.7-\infty$ \\
\hline Povorotny Cape & 52.3263 & 158.5532 & $\ddagger$ & & $10^{\S}$ & & 0 & $8.0-12.0$ \\
\hline Russian Bay ${ }^{\S}$ & 52.4097 & 158.4031 & $\ddagger$ & & $7^{\S}$ & & 500 & $5.0-9.0$ \\
\hline Zhirovaya & 52.6103 & 158.4000 & yes & 5.7 & & 499 & & $4.0-6.2$ \\
\hline Jirovaya $^{\S}$ & 52.6200 & 158.4100 & $\ddagger$ & & $4.5^{\S}$ & & 500 & $2.5-6.5$ \\
\hline Vilyuchinskaya ${ }^{\dagger}$ & 52.6540 & 158.4177 & $\ddagger$ & & 8.0 & & 500 & $7.0-9.0$ \\
\hline Sarannaya $^{\S}$ & 52.7713 & 158.4776 & $\ddagger$ & & $7^{\S}$ & & 435 & $5.0-9.0$ \\
\hline Mayachny Cape ${ }^{\S}$ & 52.8986 & 158.6998 & $\ddagger$ & & $5.7^{\S}$ & & 130 & $3.7-7.7$ \\
\hline Khalaktirka 1 & 52.9809 & 158.8292 & yes & 8.3 & & 419 & & $7.8-9.5$ \\
\hline Khalaktirka 2 & 52.9941 & 158.8477 & no & 5.6 & & 418 & & $5.1-\infty$ \\
\hline Khalaktirka 3 & 53.0091 & 158.8711 & yes & 4.7 & & 440 & & $4.2-5.8$ \\
\hline Khalaktirka 4 & 53.0646 & 158.9746 & yes & 3.9 & & 426 & & $2.9-5.0$ \\
\hline Khalaktirka 5 & 53.1008 & 159.0587 & yes & 5.1 & & 211 & & $4.6-6.0$ \\
\hline
\end{tabular}

Based on the HTDBWLD database, the 1952 Kamchatka tsunami is the most recent tsunami to have consistently recorded wave heights greater than $5 \mathrm{~m}$ in the area adjacent to the 1952 rupture (Fig. 1; Table 2). The second largest tsunami, 1960 Chile, has reported runup higher than $5 \mathrm{~m}$ in only one location in this same area in Kamchatka. Where both tsunamis were recorded at the same location, 1952 is typically about twice as large (HTDBWLD database). Older tsunamis of potentially comparable size are 1737 and the more local 1841 events (Fig. 1). Runup from the 1952 
tsunami in the Kuril Islands was generally higher than elsewhere on Kamchatka, according to historical observations, but the post-tsunami survey data indicate tsunami runup was consistently lower than observations reported in the HTDBWLD database. For example, in the town of SeveroKurilsk, the database reports the maximum tsunami height was $15 \mathrm{~m}$, but a map in the post-tsunami survey shows that tsunami runup was consistently 7-9 $\mathrm{m}$. In such instances, we used the post-tsunami survey maps rather than HTDBWLD points, which may represent maximum tsunami heights rather than runup (Fig. 3).

\section{Tsunami-Deposit Survey}

There are significant gaps in the latitudinal distribution of historical observations, which we have been able to fill in with 31 new observations from our tsunami-deposit surveys. The 1952 Kamchatka tsunami left extensive deposits all along the Pacific coasts of central and southern Kamchatka and the northern Kuril Islands. This tsunami is recent enough to make identification of deposits as being from 1952 relatively straightforward. The deposits are extensive, sometimes reaching over a kilometer inland and are old enough to be buried and preserved in stratigraphy.
Tsunamis create sedimentary deposits as they flood the coast with turbulent, turbid water. Modern and paleodeposit surveys suggest that the form and lateral extent of a tsunami deposit is the result of a variety of factors, but there is fidelity between deposit extent and actual tsunami extent. The general character of a tsunami deposit is a sand sheet that typically thins and fines landward, following topography (Dawson and Shi, 2000). Deposits are more extensive where tsunamis overtop erodible beach ridges and coastal dunes (Bourgeois et al., 1999). Many factors, from sediment availability to coastal topography to the velocity profile of the incoming and outgoing waves, play a role in sedimentation.

The maximum inland distance of a tsunami deposit (which we define as sediment inundation) and the deposit's elevation at sediment inundation (which we define as sediment runup) represent minimum estimates of tsunami extent. Tsunami deposits can only be more limited (not more extensive) than water runup and inundation, and thin, distal deposits may be difficult to recognize. How well tsunami deposits approximate runup and inundation has been studied in a few recent post-tsunami surveys. For example, in a survey following the 2006 Kuril Island earthquake and tsunami, where floating debris indicated water runup and inundation,

(a) Hypothetical example of historical observation of runup vs. tsunami height

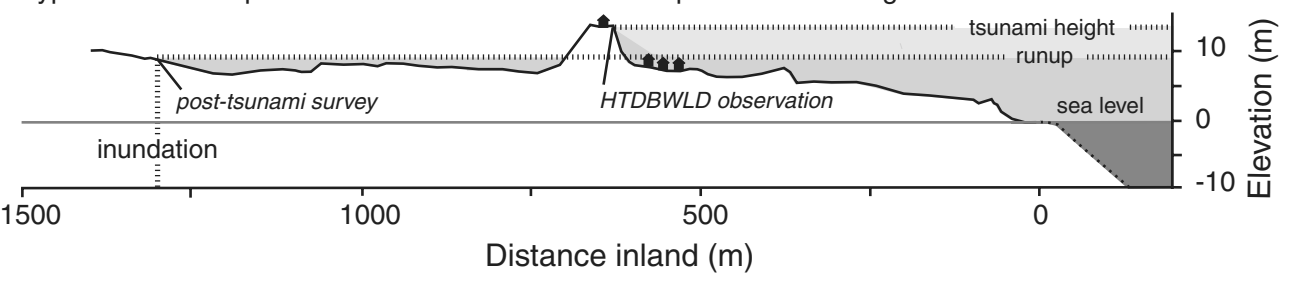

(b) Example profile with sediment inundation limit observed

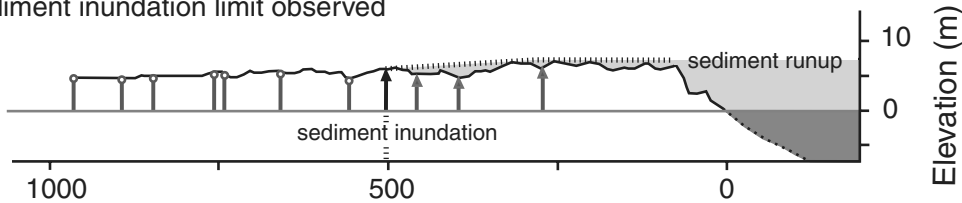

(c) Example profile with sediment inundation limit not observed

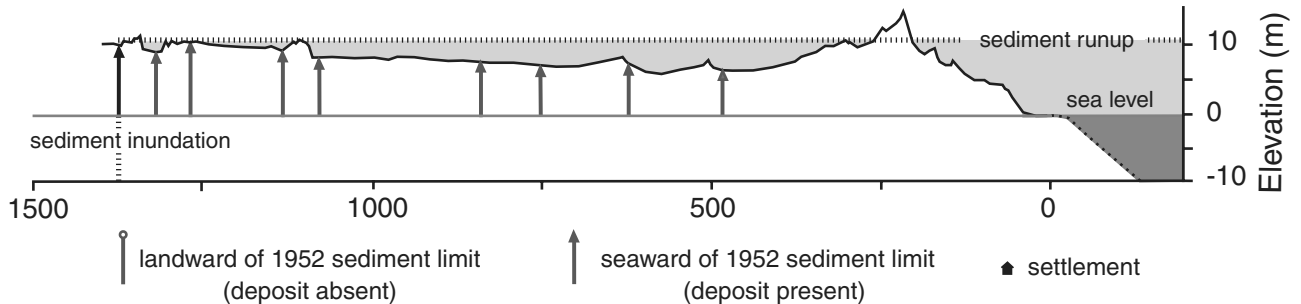

Figure 3. Example calculations of sediment runup from tsunami-deposit extent and definitions of tsunami terminology. (a) Hypothetical topographic profile showing the difference between inundation, runup, and tsunami height. Inundation and runup are both measured at the farthest inland extent of the tsunami. Tsunami height is a measure of the tsunami at any point on land other than inundation. Historical observations from the Second Navy Hydrographic Expedition post-tsunami survey (Kaistenko and Sedaeva, 2001) include measurements of runup, while values in the HTDBWLD database might be records of tsunami height rather than runup. (b) An example of a profile (Zhirovaya; see Table 1) that included the limit of sediment inundation. Sediment runup is determined from the elevation of the farthest inland deposit. (c) An example profile (Vestnik 10/11; see Table 1) where the sediment limit is beyond the profile, and the topography beyond the end of the profile was not surveyed. In these cases, our estimates of sediment runup may be too low or too high (the latter if profile elevation decreases landward). 
MacInnes et al. (2009) showed that deposits typically represented $90 \%$ of tsunami runup and inundation on sandy coastlines in the central Kuril Islands (immediately south of the 1952 rupture zone); a literature review of other post-tsunami surveys yielded similar percentages (MacInnes et al., 2009).

Deposits were classified as being from 1952 on the basis of (1) their relationship to historical volcanic ash layers; (2) the presence of other historical inclusions in deposits, such as boat debris; (3) stratigraphic position (the youngest tsunami deposit is 1952) combined with the knowledge that the runup and inundation of no other tsunami since either 1841 or 1737 was as extensive; and (4) the broad extent and sheetlike nature of the deposit ((E) see the electronic supplement to this paper for details). Our field sites are primarily sandy coastal plains, such as beach-ridge sequences, where the availability of sand maximizes the likelihood of generating and preserving tsunami deposits. We identified deposits in excavations along topographic profiles, which were measured perpendicular to the shoreline using a surveying rod with transit level or with hand level and tape (Fig. 3; methods as in Bourgeois et al., 2006).

Based on identified and mapped 1952 tsunami deposits from seven field seasons, we calculated minimum sediment runup and inundation above MSL for 31 profiles (Fig. 4; Table 1). We determined sediment runup by evaluating the presence or absence of distinct 1952 deposits in those profiles (Fig. 3). The tide in Kamchatka at the time of tsunami inundation in 1952 was rising, and was approximately -0.5 to +0.75 m MSL (E) see Fig. S1 in the electronic supplement to this paper; Harold O. Mofjeld, personal comm., 2010). We did not make corrections for tide at the time of profile measurement because we do not have accurate local tidal predictions; however, the tidal range of the northern Kuril Islands and Kamchatka is less than $2 \mathrm{~m}$. We made a distinction between profiles where the farthest landward excavation still contained the 1952 deposit and ones that did not (Figs. 3 and 4). If no deposit was present in one or more excavations landward of those containing the deposit, the limit of sediment inundation occurred within the mea- sured profile, and actual tsunami runup could be estimated from sediment runup. For profiles where the 1952 deposit extends beyond all excavations, the actual size of the tsunami could be significantly greater than our minimum estimates of sediment runup.

The Magnitude and Overall Distribution of Tsunami Runup Predicted by Field Observations

Near-field observations of the 1952 tsunami outline the distribution of tsunami runup and inundation on Kamchatka and Kuril coastal plains (Fig. 4; Table 1). For ease of discussion and comparison, we have divided the near field into three zones of approximately equal length and separated by small data gaps: (1) the northern Kuril Islands and the southernmost cape of Kamchatka $\left(\sim 50^{\circ} \mathrm{N}-51^{\circ} \mathrm{N}\right)(13$ observation points), (2) southern Kamchatka $\left(\sim 51^{\circ} \mathrm{N}-52^{\circ} \mathrm{N}\right)$ (18 points), and (3) the northern extent of the rupture zone $\left(\sim 52^{\circ} \mathrm{N}-\right.$ $\left.53^{\circ} \mathrm{N}\right)$ (17 points). Hereafter, we refer to these regions as the Kuril Islands, South Kamchatka, and Central Kamchatka, respectively.

There are higher field indicators of the 1952 Kamchatka tsunami in South Kamchatka and the Kuril Islands (Fig. 4), with deposits found up to $18 \mathrm{~m}$ above sea level and over a kilometer inland (Table 1). Almost all sediment observations in Central Kamchatka include the limit of sediment inundation, which is not the case in South Kamchatka or the Kuril Islands. Sediment runup heights and historical data are highest in the Kuril Islands, ranging from 5.4 to $16.8 \mathrm{~m}$ and averaging $10 \mathrm{~m}$. In South Kamchatka, the field observations indicate a tsunami that averaged $8 \mathrm{~m}$ runup but varied widely from 2 to $18 \mathrm{~m}$. Inundation distances are greatest, up to $1.4 \mathrm{~km}$, in South Kamchatka. In Central Kamchatka, geologic and historical data record a smaller, less variable tsunami, with a runup average of only $6 \mathrm{~m}$, ranging from 3.9 to $10 \mathrm{~m}$. In general, the geologic and historical data are consistent where both are present. In South Kamchatka, sediment data significantly fill in the region where historical data are sparse.

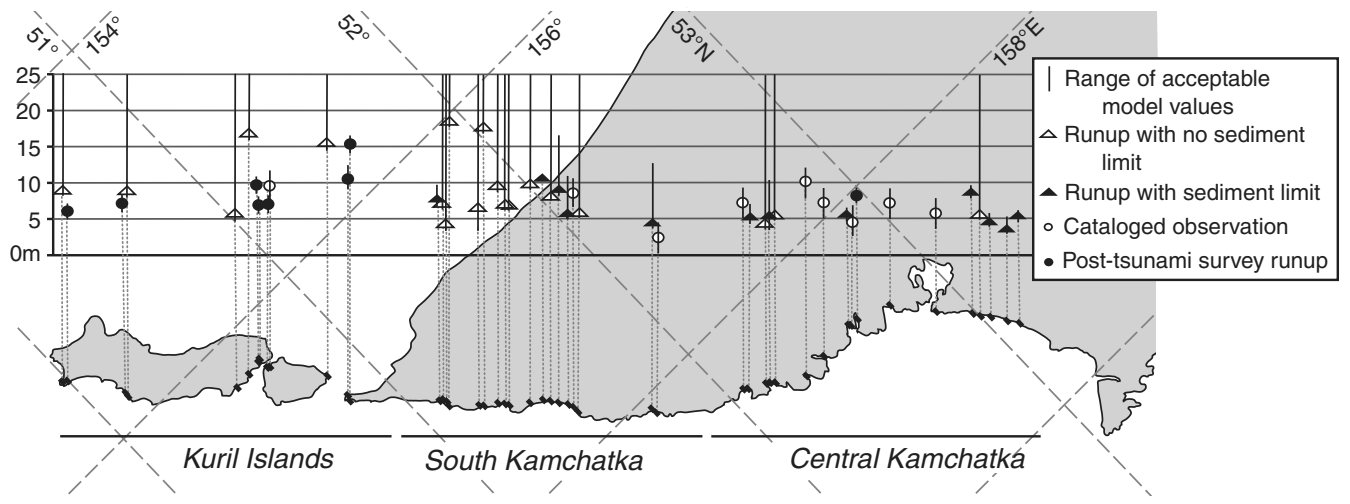

Figure 4. Field observations of the 1952 Kamchatka tsunami for 48 locations. For comparison in our analysis, we divide the near field into three areas: the Kuril Islands, South Kamchatka, and Central Kamchatka. The tsunami had higher runup in the Kuril Islands and South Kamchatka than in Central Kamchatka. For explanation of the "range of acceptable model values," see discussion in the text and Figure 6A. 


\section{Simulating the Tsunami and Earthquake Slip Distribution}

\section{MOST Tsunami Propagation and Runup Code}

In order to relate tsunami field observations to characteristics of an earthquake, we need a method for generating and propagating the tsunami from chosen configurations of seafloor displacement. We use the MOST code (Method of Splitting Tsunami; Titov and Synolakis, 1995, 1998; Titov and Gonzales, 1997), the standard forecasting model in the National Oceanic and Atmospheric Administration (NOAA) Center for Tsunami Research. MOST has been carefully tested against analytical solutions of the canonical problem (as in Hall and Watts, 1953), against results of experimental studies, and against field observations of tsunamis (Titov and Synolakis, 1995, 1998). As is common in tsunami models (Imamura, 2009; Liu, 2009), MOST numerically solves the nonlinear shallow-water wave equations for the water dynamics off- and near-shore (Titov and Synolakis, 1998; Gica et al., 2008). To compute inundation, the shoreline is treated as a moving boundary; the MOST code has the ability to handle weakly breaking waves (Titov and Synolakis, 1995). The accuracy of the computed runup depends on bathymetric and topographic grid resolution.

We converted bathymetric and topographic data for the Kuril and Kamchatka area into a $120-\mathrm{sec}(2.4-3.7 \mathrm{~km})$ resolution grid covering the entire Kamchatka and Kuril study region and, within the larger grid, a series of $3.25-\mathrm{sec}$ $(60-100 \mathrm{~m})$ resolution grids to cover field areas along the Pacific coastline () for configuration, see Fig. S2 in the electronic supplement to this paper). Telescoping grids decrease run time and allow for computation in complicated areas (Titov and Synolakis, 1998). Bathymetry was derived from the ETOPO1 1 Arc-Minute Global Relief Model (see Data and Resources section) combined with shipping charts, which we digitized. Topography was derived from our own topographic profiles and from Shuttle Radar Topography Mission (SRTM) data (see Data and Resources section).

\section{Modeling Slip Distributions}

Forward models, such as MOST, use deformation of the seafloor and sea surface as initial conditions. Because vertical displacement due to the earthquake occurs instantaneously on the time scale of a tsunami, computations of the earthquake's deformation field can be carried out separately from tsunami simulation. The homogeneous half space, after Okada (1985), is one of the standard approximations for the computation of deformation fields. The initial conditions for the Okada equations are the displacement (or slip) of the earthquake, the area in which the seismic moment is released that deforms the elastic homogeneous half space, and geometric characteristics of the fault.

We utilized NOAA's unit sources, a series of $100 \times 50 \mathrm{~km}$ grids along the subduction-zone interface (E) see Fig. S2 in the electronic supplement to this paper), to model slip distributions (Fig. 5). In the NOAA Center for Tsunami Research, a database contains unit sources mimicking standard subduction-zone earthquakes (Gica et al., 2008). In such earthquakes, the shape of the earthquake's vertical displacement is determined by elastic deformation based on the equations of Okada (1985). Unit sources assume the rupture of a single rectangular fault plane. They can be scaled through slip to consider moment magnitude $\left(M_{\mathrm{w}}\right)$ because the area of the unit sources in which the seismic moment is released is kept constant (Gica et al., 2008). Composite deformation fields, featuring patches of varying magnitude of deformation (such as those in Fig. 5), can be created by superposing deformation fields of adjacent unit sources.

We tested hypotheses for slip distributions during the 1952 earthquake (Fig. 5) that consist of homogeneous and heterogeneous patterns, including approximations of Johnson and Satake's (1999) slip-distribution pattern based on tide-gage inversions of the 1952 Kamchatka tsunami (Fig. 2). Our slip distributions maintained a total magnitude between $M_{\mathrm{w}} 8.8$ and 9.0, assuming a shear modulus of $3.5 \times 10^{10} \mathrm{~N} / \mathrm{m}^{2}$. We applied homogeneous slip to basic distribution patterns of (1) the entire rupture zone-a 700 $\times$ 200-km rectangle (Homall1, Homall4; Fig. 5), (2) slip concentrated either in the shallow or deep section of the subduction zone-700 × 100-km rectangles (Homshm2, Hommdd2; Fig 5), or (3) slip concentrated in strike-parallel groupings-300 $\times$ 200-km rectangles, which we moved north and south (Play1-Play6; Fig. 5).

For heterogeneous slip distributions, with each unit source having different slip values, we began with slip distributions based on the work of Johnson and Satake (1999) (Fig. 2) and included their error range (JAS3, JAS4, JAS5, JAS3big; Fig. 5). In search of slip distributions that better matched the near-field tsunami data, we also made modifications to Johnson and Satake's (1999) slip distribution and to homogeneous distributions (JASmod1big-JASmod5big, JASmod5-JASmod7; Fig. 5). We made these modifications based on our early results and on factors important to generating variations in near-field tsunami runup, as discussed in the Introduction and Background section.

One major effect of subduction-zone earthquakes is coseismic land-level change in the near field. Our 21 slipdistribution models produce local differences of up to a few meters of coastal coseismic uplift and subsidence (E) see Fig. S3 in the electronic supplement to this paper). However, while these differences are large enough to provide distinction between slip models, we have limited information that deformation was recorded historically, and it may not have been large enough to be noted in the locations of posttsunami surveys. Thus we cannot currently use such evidence to discriminate between models. Further investigation of evidence for land-level change could help improve slip models; however, field evidence more than 50 years after the earthquake may be difficult to unravel.

For each slip-distribution model, we computed inundation within our high-resolution bathymetric and topographic 


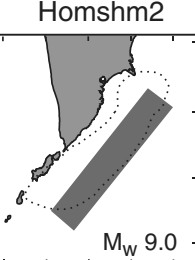

Hommdd2
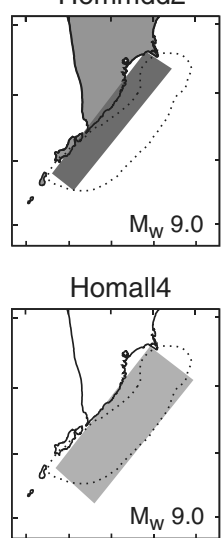

Homall1

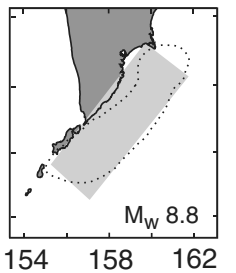

Play6

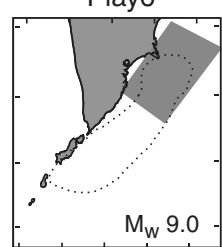

Play5

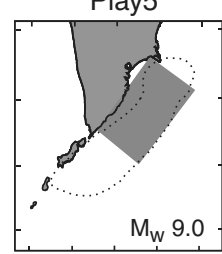

Play1

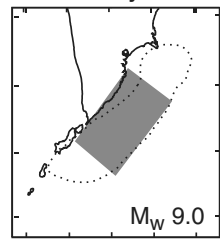

Play2

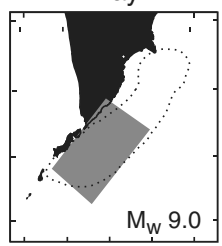

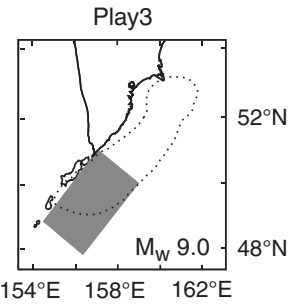

JAS3big

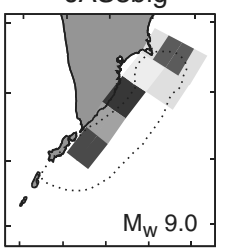

JAS5

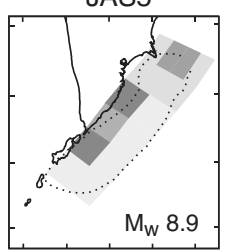

JAS3

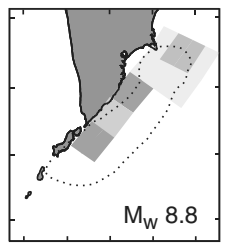

JAS4

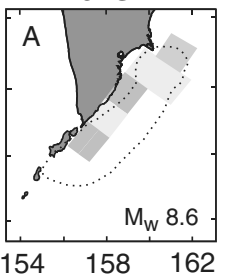

JASmod4big

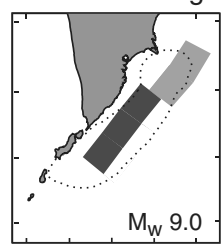

JASmod3big

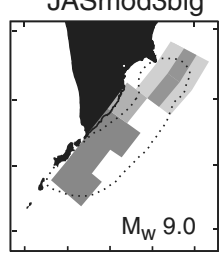

JASmod2big

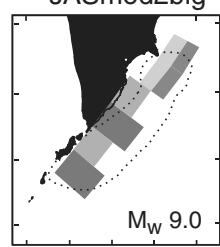

JASmod1big

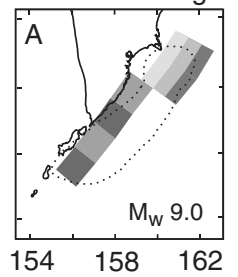

JASmod7

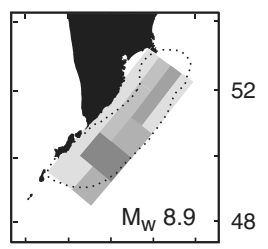

JASmod6
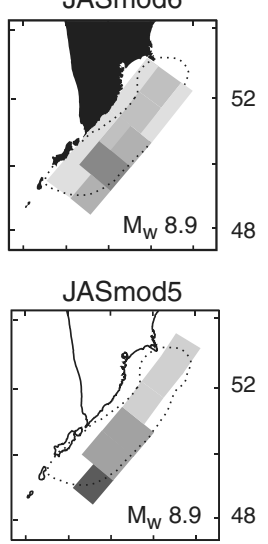

JASmod5big

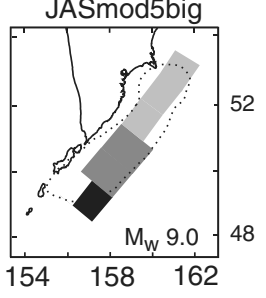

Slip (m)

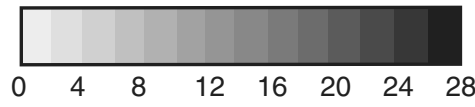

Figure 5. Slip distributions simulated in this study. The two columns on the left are homogeneous ruptures. The middle column is slip distributions based on Johnson and Satake's (1999) study, including their error range. JAS3 is their preferred slip distribution. The two columns on the right are modifications of Johnson and Satake's and the homogeneous distributions. Slip distributions with land colored in black produced best agreement (see Fig. 6, Table 3). Those with land colored in gray produced the worst agreement (Table 3). (E) Locations of unit sources and results from all simulations are included in the electronic supplement to this paper.

grids. Along the inundation line, we calculated the grid cell closest to a field-observation point and compared 1:1 the elevation of this grid cell (runup) with our field observation of runup. (E) All results are illustrated in Figs. S4-S7 in the electronic supplement to this paper, and the criteria for determining agreement between simulated runup and field observations are discussed in the next section.

\section{Evaluating the Agreement between Simulated Runup} and Field Observations

In order to evaluate the agreement between simulated runup and field observations, we implemented separate criteria for each type of field observation (Fig. 6). For example, if the limit of a deposit was mapped on a given profile, the matching criteria are stricter than in cases where the limit of a deposit was not mapped; but in both cases, the simulated tsunami must surpass the sediment runup, within an assigned measurement error of $\pm 0.5 \mathrm{~m}$, to be considered a match. Similarly, historical observations in databases are difficult to evaluate because these numbers commonly represent tsunami heights rather than runup and also may be rough estimates rather than measured points. Thus the criteria for matching observations in the HTDBWLD database are weaker than the criteria for matching mapped inundation by the posttsunami survey. Error inherent in the simulations themselves is not incorporated into our comparisons because we assume all simulations have the same kind and magnitude of error. 

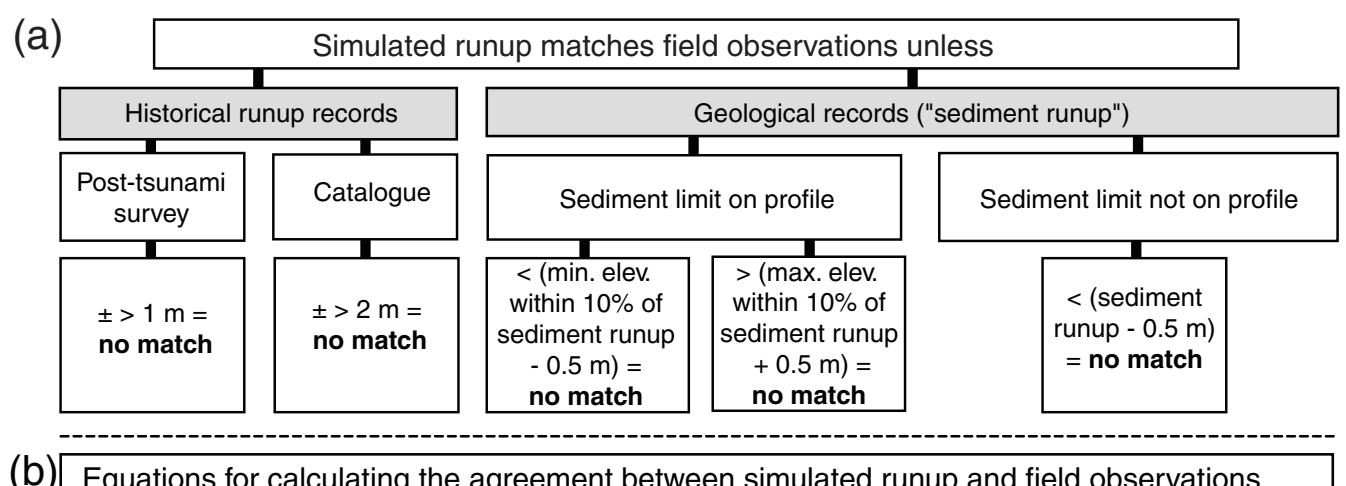

(b) Equations for calculating the agreement between simulated runup and field observations

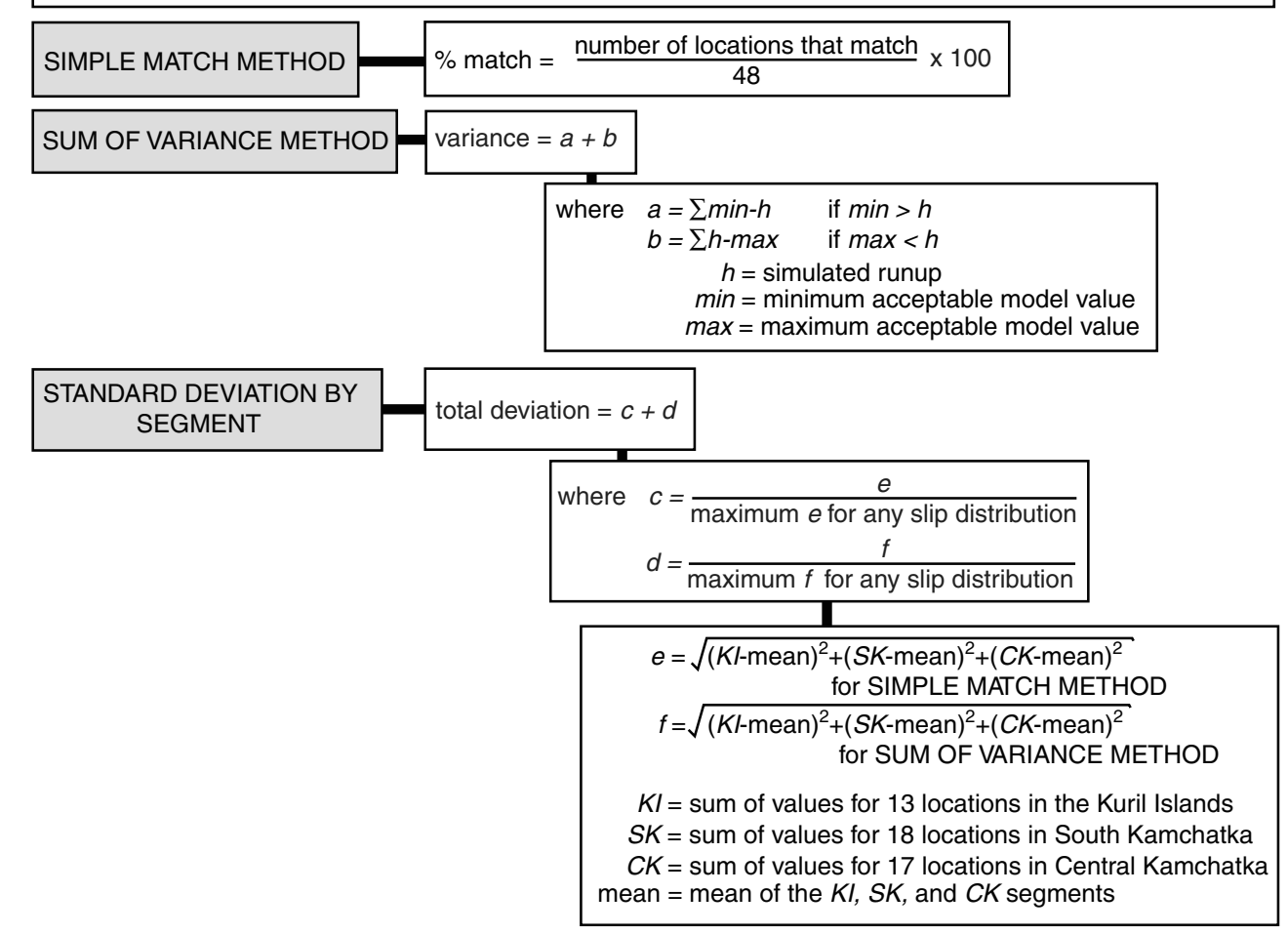

Figure 6. (a) Decision tree for determining agreement between simulated runup and field observations based on different fieldobservation data types. (b) Equations used for calculating the best-fit slip distributions. The three methods are implemented for each source model; the results are ranked and listed in Table 3.

Table 2

Historical Tsunamis* Affecting the Field Region (Fig. 1)

\begin{tabular}{|c|c|c|c|c|c|}
\hline \multicolumn{2}{|c|}{ Earthquake } & \multicolumn{4}{|c|}{ Tsunami } \\
\hline Origin & Date (dd/mm/yyyy) & $M_{\mathrm{w}}$ & $M_{\mathrm{t}}$ & Elevation in Field Area (m) & Total World Observations \\
\hline Kuril-Kamchatka & $17 / 10 / 1737$ & $\dagger$ & $\dagger$ & $10-48$ & 35 \\
\hline Kuril-Kamchatka & $22 / 08 / 1792$ & $\dagger$ & $\dagger$ & 2 & 2 \\
\hline Kuril-Kamchatka & $17 / 05 / 1841$ & $\dagger$ & 9 & $1-15$ & 7 \\
\hline Kuril-Kamchatka & $25 / 06 / 1904$ & 7.6 & $\dagger$ & $2 ?$ & 1 \\
\hline Kuril-Kamchatka & 03/02/1923 & 8.6 & 8.8 & $\dagger$ & 39 \\
\hline Kuril-Kamchatka & $04 / 11 / 1952$ & 9 & 9 & $2-18$ & 339 \\
\hline Kuril-Kamchatka & 04/05/1959 & 8 & 8 & $0.1-2$ & 12 \\
\hline Chile & $22 / 05 / 1960$ & 9.5 & 9.4 & $1-7$ & 630 \\
\hline Kuril-Kamchatka & $15 / 12 / 1971$ & 7.8 & 7.8 & $0.1-0.36$ & 15 \\
\hline Kuril-Kamchatka & 08/06/1993 & 7.5 & 7.5 & $\dagger$ & 5 \\
\hline Kuril-Kamchatka & 05/12/1997 & 7.8 & 7.7 & $\dagger$ & 13 \\
\hline
\end{tabular}


We use three methods, equally weighted, to reach our objectives that (1) simulations agree with runup of field observations, (2) simulated runup that does not agree with field observations is not excessively high or low, and (3) simulations are equally successful north to south. For each of these objectives, we used methods of comparing simulations with field data, which we call simple match, sum of variance, and standard deviation by segment (Fig. 6). In the simple match method, simulated runup either predicts individual field observations or not, with some leeway given for observation type and observation error, as discussed previously. In the case of sum of variance, each data location is scored by the variance (in meters) of simulated runup outside the acceptable limits of a match, and the score is the sum of that variance. The standard deviation of segments is the combination of the normalized standard deviation of both the simple match and sum of variance when the field area is divided into the Kuril Islands, South Kamchatka, and Central Kamchatka (Fig. 4). Those results are ranked and presented in Table 3.

No simulated tsunami completely reproduced our field observations. Because of errors inherent in both observations and tsunami simulation, our primary goal is to compare the performance of different slip distributions to each other rather than to find the perfect fit. The results from the five best-fit distributions are illustrated in Figure 7 (E) the remainder are found in the electronic supplement to this paper).

\section{The Effects of Slip Distribution}

\section{A Uniform Rupture (The Null Hypothesis) Does Not Predict Field Observations}

Homogeneous slip extending the full length of the 1952 Kamchatka rupture zone (such as distributions Homall1 and Homall4; Table 3 and Figure 5) does not produce a tsunami with runup that agrees with our field observations. The homogeneous, uniform rupture pattern is an important test of the null hypothesis. If uniform rupture matches our field observations as well as other distributions, bathymetry and topography between the source region and the fieldobservation locations would be affecting initial tsunami waveforms to the extent that signatures of a complex rupture pattern are not maintained in the near field. Homogeneous ruptures do produce relatively higher runup in South Kamchatka and the northern Kuril Islands than in Central Kamchatka, and runup in the Kuril Islands and much of South Kamchatka is too low. Thus, even if a homogeneous rupture does produce most of the field observations in Central Kamchatka, its inability to generate runup comparable to data from the more southern sites makes it an unrealistic distribution.

Commonalities of the Worst and the Best Slip Distributions

The slip distributions with the worst agreement with field observations (Fig. 5, Table 3) generally fell into three overlapping categories: either (1) they had homogeneous slip the length of the rupture, (2) moderate-to-large slip occurred in the shallowest unit sources off Central Kamchatka, or (3) the magnitude was too low. As mentioned previously, distributions without a concentration of slip could not replicate the magnitude of higher field observations observed in the Kuril Islands and South Kamchatka relative to Central Kamchatka. Shallow slip (greater than $10 \mathrm{~m}$ ) off Central Kamchatka produced runup that was too high in that sector, regardless of how well field observations matched elsewhere. Finally, slip distributions with magnitudes less than $M_{\mathrm{w}} 8.9$ consistently underestimated field observations.

Slip distributions that produced runup in best agreement with field observations (Fig. 5; Table 3) consistently had higher slip off the Kuril Islands or the south end of South Kamchatka (Fig. 7). If deeper ( $>25 \mathrm{~km}$ ), the high slip had to cover a larger area (JASmod2 and JASmod3) than if shallower $(<25 \mathrm{~km}$; JASmod6 and JASmod7). Slip-distribution Play2 showed that slip off Central Kamchatka was unnecessary to generate reasonable agreement between simulated runup and field observations; however, including moderately deep slip $(<25 \mathrm{~km})$ off Central Kamchatka, up to $10 \mathrm{~m}$ in JASmod7, produced slightly better agreement than Play 2.

The slip distribution suggested by Johnson and Satake (1999) (Fig. 2; Fig. 5: JAS3-JAS5, JAS3big) did not produce runup that agreed as well with our field observations as many other slip distributions (Table 3). Their distribution generates a simulated tsunami that matches observations in Central Kamchatka but that is too small in the Kuril Islands. While overall, Johnson and Satake's slip distribution is consistent with our interpretation of patches of higher slip off South Kamchatka, their source model is not better at matching tsunami field observations than a uniform rupture.

Our accumulated understanding of how tested slip patterns affected our tsunami simulations allowed us to modify Johnson and Satake's slip distribution (Fig. 2) to distributions that better reproduced our field observations (Table 3, Fig. 7). These modifications of Johnson and Satake's distribution have either more extensive or shallower slip in the south. More extensive slip requires adjustment elsewhere to maintain moment magnitude within our acceptable range.

\section{Effects of Slip Location and of Bathymetry}

As expected, shallower slip always produced a larger tsunami in the near field, and isolated patches of slip concentration produced adjacent correlatable peaks of tsunami runup. A $M_{\mathrm{w}} 9.0$ rupture of only the shallower unit sources on the subduction zone (Homshm2) generated a tsunami with 5-m higher runup, on average, than the same rupture of the deeper unit sources of the subduction zone (Hommdd2; Figure 5, Table 3, and (E) see Fig. S4 in the electronic supplement to this paper). Concentrations of similar magnitude slip along strike (Play1-Play6) locally increased tsunami runup by up to $10 \mathrm{~m}$.

Bathymetric effects were noticeable in our comparative studies of slip distributions. A concentration of slip in the 


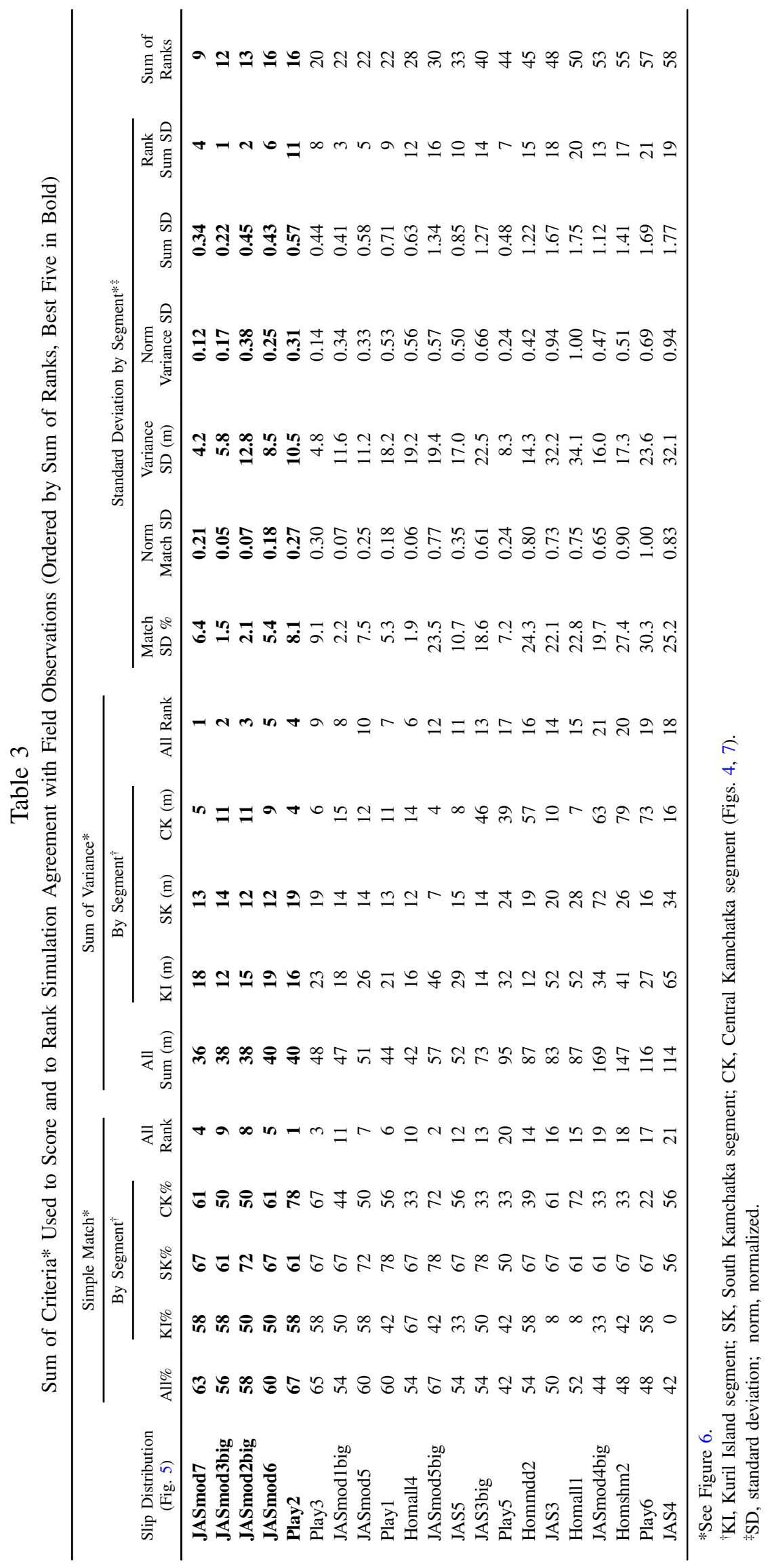



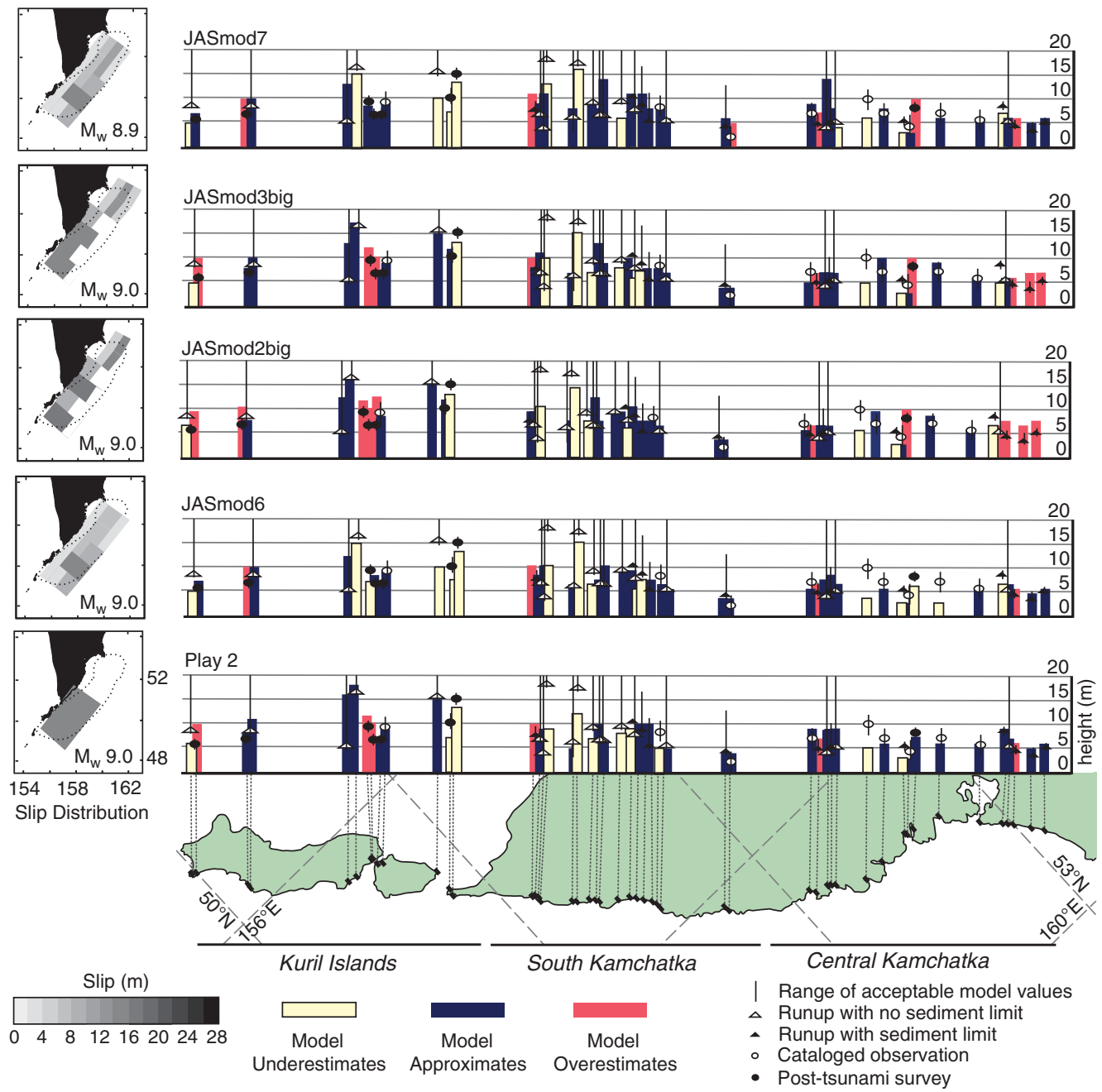

Figure 7. Best-fit distributions of slip during the 1952 Kamchatka earthquake (as in Table 3). These distributions all have concentrations of high slip off South Kamchatka or the northern Kuril Islands. The color version of this figure is available only in the electronic edition.

north (Play6) amplifies simulated runup by $\sim 7-10 \mathrm{~m}$ locally, with smaller amplifications $(\sim 3-5 \mathrm{~m})$ in the south (Play2). Also, a simulated tsunami from deeper slip produced runup that exhibited less north-south variation, while the shallower slip produced proportionally higher runup in South Kamchatka. These discrepancies are due to the tsunami originating in areas with different bathymetry and propagating across a broader, shallower continental shelf in the south versus a deeper embayment with a narrow shelf in the north.

\section{Limitations of Our Methods}

Complete agreement is unlikely for comparisons between geological data and geophysical models, each of which has limitations. In this paper, our method of generating initial tsunami waveforms (unit sources mimicking standard earthquakes) does not account for secondary effects in tsunami generation. Our method of using sediment as the means of estimating tsunami runup is inherently noisy. Also, any evaluation of our results requires us to consider whether our bathymetry and topography are accurate enough to generate realistic results.

Discrepancies between simulated and observed runup can result from wave complexity not represented in tsunami generation. Secondary processes, such as submarine slumping and splay faulting, can cause or influence tsunamis (compare Baba et al., 2006; Gisler, 2009). Timing of rupture propagation has also been shown to cause local constructive wave interference in tsunamis (Pietrzak et al., 2007). If important, these more complex formative processes of tsunamis would affect runup at only a few locations-either adjacent to the slump or splay or where the timing of rupture produces constructive interference during runup. Thus secondary processes would likely contribute to the inherent noisiness of the model-observation comparison.

An additional contributor to noisiness is that tsunamideposit extent is controlled by many factors, only one of which is the actual tsunami water runup. Issues of sediment availability, preservation, and our field techniques can occasionally make the observed sediment runup lower than the 
actual runup. For example, although we surveyed sandy shorelines, water runup can be significantly underestimated by sediment runup if the tsunami is starved. Also, thin deposits at the distal end of the sand sheet may be bioturbated beyond identification, although on Kamchatka bioturbation is weak. Even though our method of trenching is better than coring for recognition of thin deposits, it is still discontinuous and in some cases did not reach the end of a deposit.

Clearly topographic and bathymetric accuracy can affect a simulation's ability to reproduce field observations. For example, in bays in South Kamchatka, sediment runup on profiles next to each other can differ by $>10 \mathrm{~km}$ (Fig. 4) because of local topographic controls. Errors in near-shore bathymetry can influence the inundation distribution; too low resolution of near-shore bathymetry can cause dynamic processes to be underresolved in space and therefore change runup distribution. Both errors result in inaccurate representations of resonance or edge waves.

All hydrodynamic computer codes are limited by the governing equations they solve numerically. The flow dynamics of a tsunami is three dimensional and, hence, complex. In computer codes like MOST, a tsunami is simulated by twodimensional, depth-integrated approximations, which result in simplifications of flow dynamics especially near the wave front.

Our slip distributions consistently produced simulations that underestimated or overestimated a few of our observations, likely because of a combination of these factors. In attempting accurate simulation of "noisy" data, such as paleotsunami deposits, one should not expect ideal matches; as such it is valuable to use as many observations for comparison as possible.

\section{Conclusions}

For the specific case of 1952 Kamchatka, extensive field observations show that the 1952 tsunami was larger in southern Kamchatka and the northern Kuril Islands than at the northern end of the rupture zone (Fig. 4). This spatial variation in tsunami runup from field observations could not be produced by slip distributions without a concentrated area of higher slip. The general picture of slip from the 1952 event determined by our work is of high slip off southern Kamchat$\mathrm{ka}$, more extensive or shallower than suggested by Johnson and Satake (1999). Their concentration of slip at the very northern end of the rupture zone could be consistent with our observations only if the slip was neither extensive nor shallow.

For seismically active coastlines without (or with unobserved) historical tsunamis, near-field paleotsunami deposit distribution may be a valuable, but underexploited, source-model validation tool. Our study shows that using paleotsunami deposits to study paleoearthquake rupture characteristics is feasible, provided there are ample reliable observations of sediment runup.
Tsunami-deposit distributions can predict regions of large coseismic slip. Because high-slip regions are associated with locked sections of subduction zones, these regions may persist in time and be useful for studies of pre-events or postevents (Johnson and Satake, 1999; Bürgmann et al., 2005). If the 1952 earthquake's high-slip region off southern Kamchatka remains locked over multiple earthquake cycles, similarly higher tsunami runup in southern Kamchatka would be expected in the next large Kamchatka earthquake and tsunami.

\section{Data and Resources}

Historical observations of the 1952 Kamchatka tsunami, excluding the 1953 post-tsunami survey (Kaistrenko and Sedaeva, 2001), were found in the Historical Tsunami Database for the World Ocean (HTDBWLD database), maintained by the Tsunami Laboratory, Institute of Computational Mathematics and Mathematical Geophysics, Siberian Division Russian Academy of Sciences, Novosibirsk, Russia, for the United Nations Educational, Scientific and Cultural Organization's Intergovernmental Oceanographic Commission (http://tsun.sscc.ru/nh/tsunami.php; last accessed 13 November 2009).

Tsunami-deposit distribution was compiled from field observations over seven summers in the Russian Far East. Fieldwork was conducted by many, under the supervision of Tatiana Pinegina and Joanne Bourgeois.

The MOST code and the unit sources were provided by the modeling group of the National Oceanic and Atmospheric Administration (NOAA) Center for Tsunami Research (Pacific Marine Environmental Laboratory-NOAA, Joint Institute for the Study of the Atmosphere and Ocean-University of Washington). Unit sources can be found at their Propagation Database, available at http://sift .pmel.noaa.gov/thredds/catalog/data/uncompressed/catalog. html (last accessed 25 February 2010). Bathymetric grids were created in ArcGIS using the ETOPO1 1 Arc-Minute Global Relief Model (Amante and Eakins, 2009) and 1 arc-second SRTM data (Shuttle Radar Topography Mission, 1 Arc Second scene SRTM_u03_n008e004, Unfilled Unfinished 2.0, Global Land Cover Facility, University of Maryland, College Park, Maryland). ETOPO1 and SRTM data were modified with shipping charts and coastal topographic profiles measured by Pinegina and Bourgeois field teams.

\section{Acknowledgments}

This work was partially funded by the following grants: National Science Foundation (EAR-9903341 and EAR-0125787 to Bourgeois; ARC-0508109 to Ben Fitzhugh), the Russian Foundation for Basic Research (00-05-64697 and 03-05-64584 to Pinegina), and the National Geographic Society (6543-99 to Vera Ponomareva). We are grateful for helpful reviews by Heidi Houston, Roland Bürgmann, Elizabeth Clark, and an anonymous reviewer. 


\section{References}

Amante, C., and B. W. Eakins (2009) ETOPO1 1 arc-minute global relief model: Procedures, data sources and analysis, NOAA Technical Memorandum NESDIS NGDC-24, National Geophysical Data Center, U.S. Department of Commerce, Boulder, Colorado, 19 pp.

Baba, T., P. R. Cummins, T. Hori, and Y. Kaneda (2006). High precision slip distribution of the 1944 Tonankai earthquake inferred from tsunami waveforms: Possible slip on a splay fault, Tectonophysics 426, no. $1 / 2,119-134$.

Balakina, L. M. (1992). Kamchatka earthquake of November 4, 1952, and its position in the seismic events of the Kurile-Kamchatka Zone, Izvestiya Phys. Solid Earth 28, no. 6, 459-471.

Bath, M., and H. Benioff (1957). Aftershock sequence of the Kamchatka earthquake of November 4, 1952, Bull. Geol. Soc. Am. 68, 12, Part 2, 1819.

Ben-Menahem, A., and M. N. Toksöz (1963). Source mechanism from spectrums of long-period surface waves: 2, The Kamchatka earthquake of November 4, 1952, J. Geophys. Res. 68, no. 18, 5207-5222.

Borrero, J. C., R. Weiss, E. A. Okal, R. Hidyat, Arcas D. Suranto, and V. V. Titov (2009). The tsunami of 2007 September 12, Bengkulu province, Sumatra, Indonesia: Post-tsunami field survey and numerical modeling, Geophys. J. Int. 178, 180-194.

Bourgeois, J. (2009). Geologic effects and records of tsunamis, in The Sea: Tsunamis, E. N. Bernard and A. R. Robinson (Editors), Vol. 15, Harvard University Press, Cambridge, Massachusetts, 55-91.

Bourgeois, J., C. Petroff, H. Yeh, V. Titov, C. E. Synolakis, B. Benson, J. Kuroiwa, J. Lander, and E. Norabuena (1999). Geologic setting, field survey and modeling of the Chimbote, northern Peru, tsunami of 21 February 1996, Pure Appl. Geophys. 154, no. 3/4, 513-540.

Bourgeois, J., T. Pinegina, V. Ponomareva, and N. Zaretskaia (2006). Holocene tsunamis in the southwestern Bering Sea, Russian Far East, and their tectonic implications, Bull. Geol. Soc. Am. 118, 449-463.

Brune, J. N., and G. R. Engen (1969). Excitation of mantle Love waves and definition of mantle wave magnitude, Bull. Seismol. Soc. Am. 59, 923-934.

Bürgmann, R., M. G. Kogan, G. M. Steblov, G. Hilley, V. E. Levin, and E. Apel (2005). Interseismic coupling and asperity distribution along the Kamchatka subduction zone, J. Geophys. Res. 110, no. B07405, doi 10.1029/2005JB003648.

Dawson, A. G., and S. Shi (2000). Tsunami deposits, Pure Appl. Geophys. 157, 875-897.

Fedotov, S. A., S. D. Chernyshev, and G. V. Chernysheva (1982). The improved determination of the source boundaries for earthquakes of $M>7.75$, of the properties of the seismic cycle, and of long-term seismic prediction for the Kurile-Kamchatka arc, Earthq. Predic. Res. 1, 153-171.

Fedotov, S. A., S. D. Chernyshev, Y. D. Matvienko, and N. A. Zharinov (1999). The forecast of the December 1997, magnitude 7.8-7.9 Kronotsky earthquake, Kamchatka, and its $M=6$ aftershocks, Vulkanologiya i seismologiya 20,597-613; available at http://www.maik. ru/cgi-perl/journal.pl?lang=eng\&name=vulkan (last accessed April 2010).

Geist, E. L. (2002) Complex earthquake rupture and local tsunamis, J. Geophys. Res. 107, doi 10.1029/2000JB000139.

Geist, E. L., and R. Dmowska (1999). Local tsunamis and distributed slip at the source, Pure Appl. Geophys. 154, 485-512.

Gica, E., M. Spillane, V. V. Titov, C. Chamberlin, and J. C. Newman (2008). Development of the forecast propagation database for NOAA's short-term inundation forecast for tsunamis (SIFT), NOAA Tech. Memo. OAR PMEL-139, $89 \mathrm{pp}$.

Gisler, G. R. (2009). Tsunami generation: Other sources, in The Sea: Tsunamis E. N. Bernard and A. R. Robinson (Editors), Vol. 15, Harvard University Press, Cambridge, Massachusetts, 179-200.

Hall, J., and G. M. Watts (1953). Laboratory investigation of the vertical rise of solitary waves on impermeable slopes, U.S. Army, Corps of Engineers, Beach Erosion Board, Tech. Memo no. 33, 14 pp.
Hébert, H., D. Reymond, Y. Krien, J. Vergoz, F. Schindelé, and R. J. Loevenbruck (2009). The 15 August 2007 Peru earthquake and tsunami: Influence of the source characteristics on the tsunami heights, Pure Appl. Geophys. 166, 211-232.

Hirata, K., E. Geist, K. Stake, Y. Tanioka, and S. Yamaki (2003). Slip distribution of the 1952 Tokachi-Oki earthquake $(M$ 8.1) along the Kuril Trench from tsunami waveform inversion, J. Geophys. Res. 108, doi 10.1029/2002JB001976.

Hodgson, J. H. (1956). Direction of faulting in some of the larger earthquakes of the North Pacific, 1950-1953, Can. Dom. Observ. Publ. 18, 219-252.

Hutchinson, R. O. (1954). The Kamchatka earthquakes of November, 1952, Earthq. Notes 25, 37-41.

Ichinose, G., P. Somerville, H. K. Thio, R. Graves, and D. O'Connell (2007). Rupture process of the 1964 Prince William Sound, Alaska, earthquake from the combined inversion of seismic, tsunami, and geodetic data, J. Geophys. Res. 112, no. B07306, doi 10.1029/2006JB004728.

Imamura, F. (2009). Tsunami modeling: inundation, in The Sea: Tsunamis, E. N. Bernard and A. R. Robinson (Editors), Vol. 15, Harvard University Press, Cambridge, Massachusetts, 321-332.

Ishii, M., P. M. Shearer, H. Houston, and J. E. Vidale (2005). Extent, duration and speed of the 2004 Sumatra-Andaman earthquake imaged by the Hi-Net array, Nature 435, 933-936.

Johnson, J. M., and K. Satake (1997). Asperity distribution of AlaskaAleutian earthquakes: Implications for seismic and tsunami hazards, in Perspectives on Tsunami Hazard Reduction G. Hebenstreit (Editor), Kluwer Academic Publishers, Dordrecht, The Netherlands, $67-81$.

Johnson, J. M., and K. Satake (1999). Asperity distribution of the 1952 great Kamchatka earthquake and its relation to future earthquake potential in Kamchatka, Pure Appl. Geophys 154, no. 3/4, 541-553.

Kaistrenko, V., and V. Sedaeva (2001). 1952 North Kuril tsunami: New data from archives, in Tsunami Research at the End of a Critical Decade G. T. Hebenstreit (Editor), Kluwer Academic Publishers, Dordrecht, The Netherlands, 91-102.

Kanamori, H. (1976). Re-examination of the Earth's free oscillations excited by the Kamchatka earthquake of November 4, 1952, Phys. Earth Planet. In. 11, no. 3, 216-226.

Kanamori, H. (1972). Mechanism of tsunami earthquakes, Phys. Earth Planet. In. 6, no. 5, 346-359.

Kelleher, J., and J. Savino (1975). Distribution of seismicity before large strike slip and thrust-type earthquakes, J. Geophys. Res. 80, 260-271.

Lay, T., H. Kanamori, C. J. Ammon, M. Nettles, S. N. Ward, R. C. Aster, S. L. Beck, S. L. Bilek, M. R. Brudzinski, R. Butler, H. R. DeShon, G. Ekstrom, K. Satake, and S. Sipkin (2005). The great SumatraAndaman earthquake of 26 December 2004, Science 308, 1127-1133.

Liu, P. (2009). Tsunami modeling: Propagation, in The Sea: Tsunamis E. N. Bernard and A. R. Robinson (Editors), Vol. 15, Harvard University Press, Cambridge, Massachusetts, 295-319.

MacInnes, B. T., J. Bourgeois, T. K. Pinegina, and E. Kravchunovskays (2009). Tsunami geomorphology: Erosion and deposition from the 15 November 2006 Kuril Island tsunami, Geology 37, 995-998.

Martin, M. E., R. Weiss, J. Bourgeois, T. K. Pinegina, H. Houston, and V. V. Titov (2008). Combining constraints from tsunami modeling and sedimentology to untangle the 1969 Ozernoi and 1971 Kamchatskii tsunamis, Geophys Res. Lett. 35, L01610, doi 10.1029/ 2007GL032349.

McCalpin, J. (Editor), (2009). Paleoseismology, Second Ed. International Geophysics Series 95, Academic Press, New York, 613 pp.

Nikonov, A. A. (2006). Kuril'skaya katastrofa 1952 g., vyzvannaya tsunami. (Kuril catastrophe in 1952 caused by tsunami), Izvestiya Akademii Nauk, Rossiyskaya Akademiya Nauk, Seriya Geograficheskaya 2, 48-58 (in Russian).

Obermeier, S. (Editor) (2005). Paleoliquefaction and Appraisal of Earthquake Hazards, Engineering Geology 76, no. 3-4, 177-178.

Okada, R. (1985). Surface deformation due to shear and tensile faults in a half-space, Bull. Geol. Soc. Am. 75, no. 4, 1135-1154. 
Okal, E. (1992). Use of mantle magnitude Mm for the reassessment of the moment of historical earthquakes I: Shallow events, Pure Appl. Geophys. 139, 17-57.

Okal, E. A. (2009). Excitation of tsunamis by earthquakes, in The Sea: Tsunamis E. N. Bernard and A. R. Robinson (Editors), Vol. 15, Harvard University Press, Cambridge, Massachusetts, 137-177.

Okal, E. A., and C. E. Synolakis (2004). Source discriminants of near-field tsunamis, Geophys. J. Int. 158, 899-912.

Pelayo, A. M., and D. A. Wiens (1992). Tsunami earthquakes: Slow thrust-faulting events in the accretionary wedge, J. Geophys. Res. 97, 15321-15337.

Pietrzak, J., A. Socquet, D. Ham, W. Simons, C. Vigny, R. J. Labeur, E. Schrama, G. Stelling, and D. Vatvani (2007). Defining the source region of the Indian Ocean Tsunami from GPS, altimeters, tide gauges and tsunami models, Earth Planet. Sci. Lett. 261, 49-64.

Satake, K., and B. F. Atwater (2007). Long-term perspectives on giant earthquakes and tsunamis at subduction zones, Ann. Rev. Earth Planet Sci. 35, 349-374.

Satake, K., and Y. Tanioka (1999). Sources of tsunami and tsunamigenic earthquakes in subduction zones, Pure Appl. Geophys. 154, 467-483.

Satake, K., F. Nanayama, and S. Yamaki (2008). Fault models of unusual tsunamis in the 17th century, Earth Planets Space 60, 925-935.

Satake, K., F. Nanayama, S. Yamaki, Y. Tanioka, and K. Hirata (2005). Variability among tsunami sources in the 17th-21st centuries along the southern Kuril Trench, in Tsunamis: Case Studies and Recent Developments, K. Satake (Editor), Vol. 23, Advances in Natural and Technological Hazards Research, Kluwer Academic Publishers, Boston, Massachusetts, 157-170.

Soloviev, S. L., and C. N. Go (1984). A catalogue of tsunamis on the western shore of the Pacific ocean, Nauka Publishing House, Moscow, 1974, translated from Russian to English by Canadian Institute for Science and Technical Information, No. 5077, National Research Council, Ottawa, Canada, 439 pp.
Tadepalli, S., and C. E. Synolakis (1996). Model for the leading waves of tsunamis, Phys. Rev. Lett. 77, 2141-2144.

Titov, V. V., and F. I. Gonzales (1997). Implementation and testing of the methods of splitting tsunami (MOST) model, Technical Report NOAA Tech. Memo. ERL PLEL-112 (PB98-122773), NOAA/Pacific Marine Environmental Laboratory, Seattle, Washington, $11 \mathrm{pp}$.

Titov, V. V., and C. E. Synolakis (1995). Modeling of breaking and nonbreaking long-wave evolution and runup using VTCS-2, J. Waterw. Port Coast. Ocean Eng. 121, 308-316.

Titov, V. V., and C. E. Synolakis (1998). Numerical modeling of tidal wave runup, J. Waterw. Port Coast. Ocean Eng. 124, 157-171.

Zayakin, Y. A., and A. A. Luchinina (1987). Catalogue of Tsunamis on Kamchatka, Vniigmi-Mtsd, Obninsk, Russia, 50 pp. (in Russian).

Department of Earth and Space Sciences

University of Washington

Seattle, Washington 98195

(B.T.M., J.B.)

Department of Geology and Geophysics

Texas A\&M University

College Station, Texas 77845

(R.W.)

Institute of Volcanology and Seismology

Far Eastern Branch, Russian Academy of Sciences

Petropavlovsk-Kamchatskiy, 683006, Russia

(T.K.P.)

Manuscript received 8 December 2009 